\title{
Survey Mile
}

National Cancer Institute

\section{Source}

National Cancer Institute. Survey Mile. NCI Thesaurus. Code C71184.

A traditional unit of distance equal to 5280 survey feet or to approximately 1609.347

meters. This unit is used for geodetic purposes by the United States Public Land Survey System. 